\title{
UNDERWRITING CYCLES AND COMPETITION IMPACT IN EVALUATION OF INSURANCE COMPANY'S EFFECTIVE STRATEGY
}

\author{
I.A.Tetin, ilya.tetin@susu.ru \\ South Ural State University, Chelyabinsk, Russian Federation
}

\begin{abstract}
The paper considers competition accounting in evaluation of effective strategy of insurance company with underwriting cycle. We describe the dynamics of competition in the insurance market and show the relation of competitive interactions with the change of phases of soft and hard market. Regions where the shifts of loss ratios occur are discovered. The values of the competitive effect of the trend for decreasing and increasing rates are estimated, and recommendations on the determination of competitive effect for reducing the effects of level shifts and loss in discovered regions are given.
\end{abstract}

Keywords: underwriting cycle, competition accounting, strategy of insurance company.

\section{Introduction}

Two types of cyclic behavior exist in the insurance market: irregular short-term fluctuations and the regular up and downswings that occur every few years - underwriting cycles [1]. Their presence in Russia's insurance market as a whole and for individual lines of business were statistically proven for the first time in [2]. Further research established that the cyclicity of the Russian insurance market can be estimated by the dynamics of macroeconomic indicators [3]. Foreign researches [4] showed that the development of the insurance market will inevitably lead to increased competition, which is the driving force of cyclicality. Revealing the specific impact of competitive interactions on the predicted values of the underwriting cycle is very difficult, see [2].

In addition, to create realistic models of competitive behavior of insurance market participants, it is necessary to consider asymmetric flows of information, possible manifestations of opportunism, and the very nature of human behavior. However, the effects of competition on the dynamics of insurance premiums and their consequences are obvious. Correlating with each other, competitive interaction and change of macroeconomics state [5,6] may lead to a synergistic effect that shifts the future loss ratios.

One of the ways to account for such shifts in the loss ratios is to adjust insurance rates with the forecasted change in market conditions. For this purpose, we include in the mathematical model of the insurance company two indicators: the overall level of competition and the competitive effect, which determines the importance of current level of competition on the line of business to modify the insurance rates for this line.

This work continues our research made by the author and considers the control parameters of the competitive effect to reduce the consequences of level shifts and losses caused by the competitive interaction of participants in the insurance market.

\section{Underwriting cycles and competition effects}

We define underwriting cycle as a regular change of phases of "soft" and "hard" market. A soft market is characterized by low yields, low prices, excess of insurance supply over demand, while the hard market is characterized by high prices, high yield and limited supply of insurance coverage [7].

Let insurance companies $j \in J(t)$ operate in discrete time $t$. Each company has its own portfolio of insurance risks with the size $n_{j}(t), \sum_{j=1}^{J} n_{j}(t)=N(t)$, where $N(t)$ is the market volume (the number of insured risks), besides that $N(t) \leq \tilde{N}$ where $\tilde{N}$ defines the total amount of insured risks and risks available for insurance. 


\section{Краткие сообщения}

The replenishment amount of the insurance portfolio depends on two parameters: the reputation of the company $R_{j}$, which is considered in all lines of business and the market value of the insurance rate $\left[T_{m, j}(t)\right]_{l}$, applicable for a particular line $l \in L_{j}$, where $L_{j}$ is the number of lines of business of the company $j ; m$ in the index means the market rate. The market is segmented, and companies belonging to one segment have approximately the same reputation, so the competition in the segment drives mainly with the size of insurance rates [8].

So, the main factor of competitive behavior is the value of the insurance rate. To set the appropriate value of insurance rate, companies take into account present market conditions (by inserting $h$ the level competition). Also they take into account the average insurance rate of the previous period $\bar{T}_{m, n}(t-1)$. Therefore, the value of the market insurance rate is a function of these parameters

$$
\left[T_{m, j}(t)\right]_{l}=f\left(h, \bar{T}_{m, n}(t-1),\left[T_{b, j}(t)\right]_{l}\right),
$$

and $\left[T_{b, j}(t)\right]_{l}-$ is the gross insurance rate which is determined based on the probabilistic characteristics of insurance risk with actuarial methods. When the company introduces the rate which is lower than the average rate of the market segment, the company becomes more attractive to policyholders. On the contrary, a company with higher insurance rates will lose customers.

We describe the dynamics of competition in the insurance market, causing shifts in loss ratios. Companies exploit the passiveness of their clients and increase prices. They do so in order to increase the profitability of their insurance portfolios and expect the same behavior from the other participants. If the rest of them start following this trend, then the market will be evident to an accelerated trend of rising prices (see Fig. 1, "stage 4"). As companies are interested in operating profitability, they increase the requirements for the customers for taking their risks into the insurance and get rid of the bad risks in insurance portfolios. Consequently, it follows with the deficit of coverage $[9,10]$, i.e. $\tilde{N}-N(t)>\delta$.

Along with the high level of prices, this situation becomes attractive to new business and some new companies may enter the market to get their piece of the pie (see Fig. 1, "stage 5").

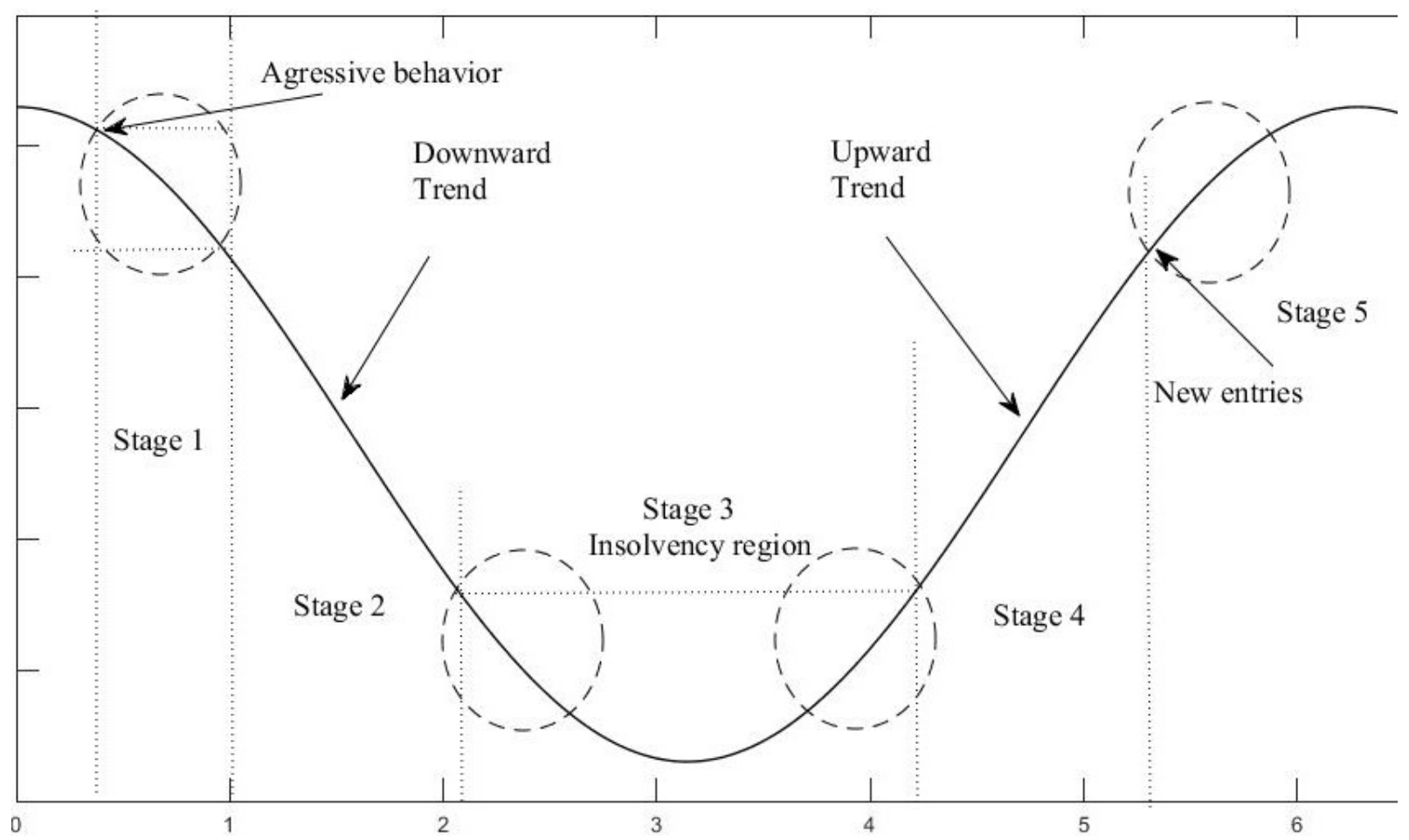

Fig. 1. Competition dynamics in the insurance market 
Fig. 1 schematically shows a cycle of competition in the insurance market, according to the $\mathrm{x}$-axis reflects time and the y-axis the average value of insurance rates. Ellipses note the areas in which shifts in the levels of losses happens.

New market entrants take bad insurance risks, but to ensure their solvency, they also need good risks in the insurance portfolios. In the absence of reputation of newcomers in the market, the only way to attract customers is the price factor. So this companies are forced to significantly reduce prices below the market average. This behavior is called aggressive (see Fig. 1, "stage 1"). Price sensitivity of policyholders start to increase, and willingness to switch the insurance company to a new one with lower price also grows. The greater the difference between the insurance rates, the greater the flow of risks will be from the company with high insurance rates to the company with low insurance rates. The larger the company size is the less amount of policyholders will be their keenness to switch to another company. We can set such behavior of policyholders by the formula of a simple risk flow:

$$
\forall r, s \in(1,2, \ldots, J): \alpha_{r s}(t)=\max \left\{0, T_{m, r}(t)-T_{m, s}(t)\right\} \cdot m_{s}(t),
$$

where $r$-company-transmitter, $s$ - the receiver company, $T_{m}(t)$ - insurance rate, $m_{s}(t)$ - the size of the company's receiver, $\alpha_{r s}(t)$ - is an absolute value for the risk flow. Let us define a transition function number of risks:

$$
\tau_{r s}(t)=1-\exp ^{-k_{4} \cdot \alpha_{r s}(t)},
$$

where $k_{4}$ - coefficient of elasticity.

Since the market price remains predictable, some insurance companies may realize that by setting individual prices slightly lower than the average price of the last period, they could get more income and increase the size of the insurance portfolio despite the increase in the loss ratio. If the company sets the price higher than the market average, the effect will be the opposite: lower income and migration of customers, but higher solvency and lower probability of bankruptcy due to insolvency. Aggressive company forecasting the expected decline of average market prices, should bring even lower prices to the market.

The downward trend starts with falling of insurance rates (see Fig. 1, "stage 2"). One after another, insurance companies driven by mercantile interests' lower individual rates after exploring the average market price of previous period. They expect the same behavior from other market participants, this leads to a further drop in prices. This trend is spreading to other market players who join the first group that puts pressure on the market price, making it less predictable. The price reduction causes an increase in the number of policyholders, sensitive to changes in price, therefore, increases the desire to find a lower price and increases the transition flow of clients towards companies with lower prices. Those companies that tried to resist the trend will leave the market or stop sales in the line of business, and the market will remain only the players who follow relevant trend (see Fig. 1, "stage 3").

Insolvency of market participants takes place, and insurers understand that further fall in the rates will lead to insolvency. Media publish data on massive insolvencies. From this point insurers start selling their portfolios to keep up with the solvency indicators. Those who cannot reach solvency withdraw from the market, the others collect the benefits of new market shares. Aggressive companies stop following their market conquering strategies. Policyholders are frightened by the potential loss of protection and break seeking for lower prices on the market, migration of customers between companies is reduced. Then the companies start raising prices in order to increase their solvency on current insurance portfolios (see Fig. 1, "stage 4"). The upward trend followed by other participants. Further increasing of rates and strengthening of underwriting rules makes the companies get rid of bad risks. Lack of insurance cover creates the potential $\tilde{N}-N(t)>\delta$ and the competition cycle repeats again.

\section{Accounting the impact of competition}

In [6] we have shown that rationally generated insurance rate in the period $t$ for the line of business $l$ is calculated as follows:

$$
\left\{T_{m, j}^{O}(t)=T_{b, j}^{O}(t) \cdot\left[k_{1, j}(t) \cdot\left(\frac{T_{m, j}^{O}(t-1)}{\bar{T}_{m, n}(t-1)}\right)^{-h_{1}}+\left(1-k_{1, j}(t)\right)\right]\right\}_{l},
$$




\section{Краткие сообщения}

here $T_{m, j}^{O}(t)$ - rationally determined market wage rate, $T_{b, j}^{O}(t)$ - rationally generated gross rate, $\bar{T}_{m, n}(t-1)$ - average market rate for the previous period, $h_{1}$ - intensity of competition, finally $k_{1, j}(t)-$ competitive impact. The competitive impact shows how important the level of competition needed for modification of insurance rates is. We have also shown that the most effective strategy in terms of underwriting cycle is a mixed strategy, in which the value of the competitive impact is enclosed in $0<k_{1, j}(t)<1$.

At the stage 2 and stage 4, where the downward and upward trend is established, the company's goal will be to ensure the solvency, otherwise the company will be forced to leave the market, so the value of competitive impact has to be estimated from the formula:

$$
k_{1, j}(t)=\frac{\frac{R_{j}(t)+\mathrm{C}_{t o t a l, j}(t)+\mathrm{E}_{u, j}(t)}{\sum_{q=1}^{Q} G_{q}}-I_{L, j}(t)-I_{H, j}(t)+E_{i, j}(t)}{T_{b, j}(t) \cdot\left[\left(\frac{T_{m, j}^{O}(t-1)}{\bar{T}_{m, n}(t-1)}\right)^{-h_{1}}-1\right]},
$$

with the restrictions on $\left(S_{j}(t)-\max \left(\operatorname{tax} \cdot\left(S_{j}(t)\right), 0\right)\right) \geq 0$, where $S_{j}(t)$ - the company's net profit before tax. The values $R_{j}(t), \mathrm{C}_{\text {total }, j}(t), \mathrm{E}_{u, j}(t)$ represent estimates of the true values of costs, claims paid, and the costs insurance companies have before the correction of the market rate with the value of competitive impact, $I_{L, j}(t)$ - return on investment in risk-free assets, $I_{H, j}(t)$ - yield on investments in risky assets, $E_{i, j}(t)$ - costs of investment, $G_{q}$ - the value of insured $q$ object, $T_{m, j}^{O}$ - rationally determined market rate, $\bar{T}_{m, n}$ - average rate in the market segment. The economic meaning of such behavior is to act as the market, keep market share and maintain solvency. There are almost no shifts in loss ratios at these stages.

Stage 1 - the value of the competitive effect should be established from the solution of the optimization problem with the following parameters: the current level of solvency, the value of the potential, the average market level of profitability, price elasticity, size of the company. The smaller the company size, the more aggressive the strategy it may use, therefore, the less focus on the competition will be.

If competitors of the company follow the strategy of conquering the market, the company needs to respond, but the optimal response depends on the number of competitors who reduce insurance rates. If the percentage of companies following the strategy of aggressive growth is small, it would be prudent to maintain prices above the level of marginal cost. Suppose that $10 \%$ of companies occupy $10 \%$ market share, the decline in their insurance rates ensure a $10 \%$ growth in their market shares, then a year later, these firms will be at $11 \%$ market share, and their competitive rents will remain $89 \%$ of the market. Thus, the strategy of maintaining high prices leads to a loss of $1 \%$ of market share - a small price compared to those of tabernacles profit. If $50 \%$ of companies are aggressively reducing prices, this will change the result. The same $10 \%$ increase in market share will reduce market share of the remaining firms from 50 to $45 \%$. Short term profit is hardly comparable with the $10 \%$ loss of market share.

Thus, the phase of the hard market for the underwriting cycle is in a non-equilibrium situation, some companies are satisfied with current revenues, others reduce the rates in search of market share.

In Stage 3 the value of the competitive impact can be found from the optimization of characteristics of the state vector. This vector should be optimized on the end of the current phase of underwriting cycle. The input parameters of this optimization problem will be estimated length of the underwriting cycle, financial performance of the company, properties of insurance and investment portfolios. Note that it is necessary to apply adaptive control in the insurance. It differs from the optimal control with its goal: it used not for the maximization of a certain parameter, but to keep process within acceptable boundaries for a long time. Therefore, the quality of adaptive control is not unique. In fact, the insurance company has many controllable parameters, different combinations of them give the similar result. 
Another possible way to find the values of competitive impact in Stage 3 is to use the company size parameter: the bigger the company, the smaller the value of the competitive impact it should establish, because the loss from the reduction in rates on current market share exceeds the benefits from increasing market share.

Stage 5, the value of the competitive impact should be set close to zero, since the price elasticity of policyholders is low and the company should maximize the yield of its portfolio by increasing rates, it should not follow the market.

\section{Conclusion}

In this paper we have highlighted how the company should consider the level of competition at work in the cycle of insurance activities. The main feature of insurance rates in the market is that they do not passively reflect built-in parameters, but also include the correction parameters to account for the level of competition. Insurance pricing depends on the statistical characteristics of the object of insurance, the strategy followed with the company and parameters used for compensation of the unpredicted volatility caused by underwriting cycle. These options vary depending on the stage of the actuarial determination of the price. After that when market features are determined, competition impact is included in the insurance rate. We have identified regions where shifts in loss ratios due to competitive interactions happen. Then we have given recommendations for determination of competitive effect in order to reduce the consequences of these shifts.

The reported study was funded by RFBR according to the research project no. 16-36-00024 "мол_а".

\section{References}

1. Venezian E.C. Ratemaking Methods and Profit Cycles in Property and Liability Insurance. Journal of Risk and Insurance, 1985, 52, pp. 477-500. DOI: 10.2307/252782

2. Tetin I.A. [The Presence of Underwriting Cycles in Russia]. Bulletin of Tomsk State University. Economics, 2014, no. 4 (28), pp. 114-124. (in Russ.)

3. Tetin I.A. [Underwriting Cycle in Russia and Macroeconomic Indicators]. Applied Econometrics, 2015, 39 (3), pp. 65-83. (in Russ.)

4. Leng C-C., Meier U.B. Analysis of Multinational Underwriting Cycles in Property-Liability Insurance. Journal of Risk Finance. 2006, 7, pp. 146-159. DOI: 10.1108/15265940610648599

5. Guo F., Fung H-G., Huang Y.S. The dynamic impact of macro shocks on insurance premiums. Journal of Financial Services Research. 2009, 35, pp. 225-244. DOI: 10.1007/s10693-009-0052-0

6. Malinovskii, V. K. Competition-Originated Cycles and Insurance Strategies, ASTIN Bulletin. 2010, 40, pp. 797-843.

7. Feldblum, S. Underwriting Cycles and Insurance Solvency. Casualty Actuarial Society Discussion Paper Program Casualty Actuarial Society, 2007.

8. Panyukov A.V., Tetin I.A. [Management of Investment Portfolio of the Insurance Company]. Bulletin of South Ural State University. Series Economics and Management, 2012, № 22 (281), pp. 77-83. (in Russ.)

9. Gron A. Evidence of capacity constraints in insurance markets. Journal of Law and Economics, 1994, 37, pp. 349-377. DOI: $10.1086 / 467317$

10. Winter R.A. The Dynamics of Competitive Insurance Markets. Journal of Financial Intermediation, 1994, 3, pp. 379-415. DOI: 10.1006/jfin.1994.1011

Received 20 September 2016 


\title{
ЦИКЛЫ АНДЕРРАЙТИНГА И ЭФФЕКТЫ КОНКУРЕНЦИИ В ОПРЕДЕЛЕНИИ ЭФФЕКТИВНОЙ СТРАТЕГИИ СТРАХОВОЙ КОМПАНИИ
}

\author{
И.А. Тетин \\ Южно-Уральский государственный университет, г. Челябинск
}

\begin{abstract}
Рассматриваются вопросы учета конкуренции при определении стратегии поведения страховой копании в условиях цикла страховой деятельности. Описана динамика конкуренции на страховом рынке. Показана связь конкурентного взаимодействия компаний со сменой периодов «мягкого» и «жесткого» рынков. Обнаружены области, в которых происходят сдвиги уровней убыточности. Определены значения конкурентного эффекта для тренда снижения и повышения ставок, а также даны рекомендации по определению величины конкурентного эффекта для снижения последствий сдвигов уровней убыточности в обнаруженных областях.
\end{abstract}

Ключевые слова: ичикл андеррайтинга, учет конкуренциии, стратегия страховой компании.

Работа профинансирована РФФИ, проект № 16-36-00024 «мол_а».

Jumepamypa

1. Venezian, E.C. Ratemaking methods and profit cycles in property and liability insurance / E.C. Venezian // Journal of Risk and Insurance. - 1985. - 52. - P. 477-500. DOI: 10.2307/252782

2. Тетин, И.А. Присутствие ииклов андеррайтинга в России / И.А. Тетин // Вестник Томского государственного университета. Экономика. - 2014. - № 4. - С. 114-124.

3. Тетин, И.А. Цикль страховой деятельности и макроэкономические показатели / И.А. Тетин // Прикладная эконометрика. - 2015. - № 3. - C. 65-83.

4. Leng, C-C. Analysis of multinational underwriting cycles in property-liability insurance / C-C. Leng, Meier U.B. // Journal of Risk Finance. - 2006. - 7. - P. 146-159. DOI: $10.1108 / 15265940610648599$

5. Guo, F. The dynamic impact of macro shocks on insurance premiums / F. Guo, H-G. Fung, Y.S. Huang // Journal of Financial Services Research. - 2009. - 35. - P. 225-244. DOI: 10.1007/s10693-009-0052-0

6. Malinovskii, V.K. Competition-Originated Cycles and Insurance Strategies / V.K. Malinovskii // ASTIN Bulletin. - 2010. - 40. - P. 797-843.

7. Feldblum, S. Underwriting Cycles and Insurance Solvency / S. Feldblum // Casualty Actuarial Society Discussion Paper Program Casualty Actuarial Society. - 2007.

http://www.casact.org/pubs/dpp/dpp92/92dpp383.pdf

8. Панюков, А.В. Управление инвестиционным портфелем страховой компании / А.В. Панюков, И.А. Тетин // Вестник Южно-Уральского государственного университета. Серия «Экономика и менеджмент». - 2012. - № 22 (281). - C. 77-83.

9. Gron, A. Evidence of capacity constraints in insurance markets / A. Gron // Journal of Law and Economics. - 1994. - 37. - P. 349-377. DOI: 10.1086/467317

10. Winter, R.A. The dynamics of competitive insurance markets / R.A. Winter // Journal of Financial Intermediation. - 1994. - 3. - P. 379-415. DOI: 10.1006/jfin.1994.1011 
Тетин Илья Алексеевич, канд. экон. наук, доцент кафедры финансов, денежного обращения и кредитов, Южно-Уральский государственный университет, г. Челябинск; ilya.tetin@susu.ru.

Поступила в редакцию 20 сентября 2016 г.

\section{ОБРАЗЕЦ ЦИТИРОВАНИЯ}

Tetin, I.A. Underwriting Cycles and Competition Impact in Evaluation of Insurance Company's Effective Strategy / I.A. Tetin // Вестник ЮУрГУ. Серия «Компьютерные технологии, управление, радиоэлектроника». - 2016. - Т. 16, № 4. - C. 155-161. DOI: $10.14529 / \operatorname{ctcr} 160419$

\section{FOR CITATION}

Tetin I.A. Underwriting Cycles and Competition Impact in Evaluation of Insurance Company's Effective Strategy. Bulletin of the South Ural State University. Ser. Computer Technologies, Automatic Control, Radio Electronics, 2016, vol. 16, no. 4, pp. 155-161. DOI: $10.14529 /$ ctcr160419 